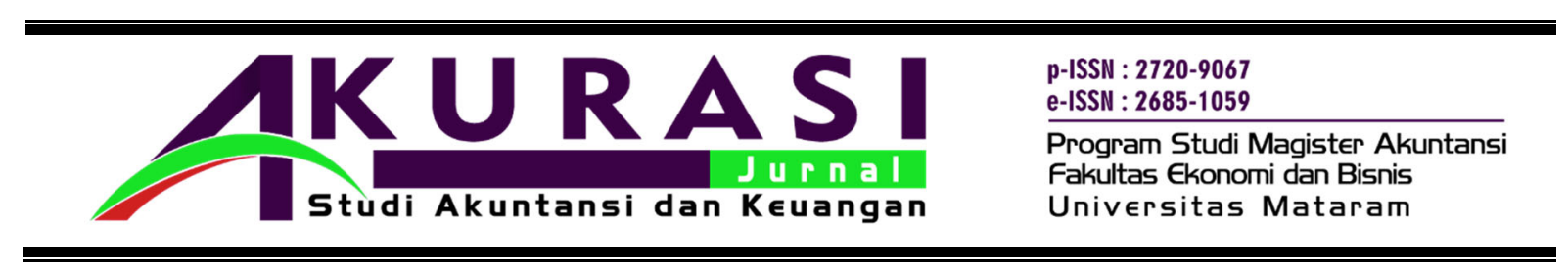

\title{
STUDI DESKRIPTIF OPPORTUNISTIC BEHAVIOR DALAM PENGELOLAAN KEUANGAN DESA
}

\author{
Erna Supiani ${ }^{1}$ \\ Universitas Mataram \\ ${ }^{I}$ Corresponding author: erna.supiani97@gmail.com
}

\section{INFORMASI ARTIKEL ABSTRAK}

Article history:

Dikirim tanggal : 23/9/2019

Revisi pertama tanggal:24/3/2020

Diterima tanggal: $5 / 5 / 2020$

Tersedia online tanggal 15/6/2020
Penelitian ini bertujuan untuk memahami pengelolaan keuangan desa dari tahap perencanaan, pelaksanaan, pelaporan, dan pertanggungjawaban dan mendeskripsikan pola perilaku oportunistik yang berpotensi terjadi dalam pengelolaan keuangan desa. Jenis penelitian ini adalah penelitian kualitatif deskriptif dengan pendekatan studi kasus. Jenis dan sumber data yang digunakan adalah data primer dan data sekunder. Teknik pengumpulan data dilakukan dengan wawancara tanya jawab secara langsung kepada informan penelitian, observasi dan dokumentasi. Hasil penelitian menunjukkan pengelolaan keuangan desa dalam tahap perencanaan selalu melibatkan masyarakat. Namun demikian, perilaku oportunistik seringkali terjadi pada tahap pelaksanaan yang tidak sejalan dengan yang direncanakan dan pelaporan pengelolaan keuangan desa yang tidak sesuai dengan kegiatan yang dilaksanakan karena diindikasikan terjadi mark-up nilai anggaran dari yang seharusnya. Manipulasi laporan keuangan diindikasikan juga terjadi pada tahap pelaporan dan pertanggungjawaban pengelolaan keuangan desa.

Kata Kunci: Pengelolaan Keuangan Desa, Perilaku Oportunistik

\section{ABSTRACT}

This study discusses village financial management, planning, implementation, reporting and accountability and to describe the opportunistic patterns carried out in village financial management. This type of research is a descriptive qualitative research with case studies. Types and sources of data used are primary data and secondary data. Data collection techniques are done by interviewing questions and answers directly to research informants, observations and documentation. The results showed that village financial management in planning always involved the community. However, opportunistic behavior often occurs at the stage of implementation that is not in line with the planned and reporting village financial management that is not in accordance with the activities carried out because it indicates a mark-up of the budget value than it should. Manipulation of financial statements is also indicated in the reporting and accountability of village financial management.

Keywords: Village Financial Management, Opportunistic Behavior 


\section{Pendahuluan}

Dalam tata pemerintahan Negara Kesatuan Republik Indonesia, istilah desa tidak asing lagi bagi kita semua. Desa merupakan unsur terkecil dalam tata administrasi pemerintahan. Di Indonesia terdapat 74.954 desa yang didiami lebih dari setengah jumlah penduduk Indonesia. UU No. 6 Tahun 2014 tentang desa menyatakan bahwa desa adalah desa dan adat atau yang disebut dengan nama lain, yang selanjutnya disebut desa, adalah kesatuan masyarakat hukum yang memiliki batas wilayah yang berwenang untuk mengatur dan mengurus urusan pemerintahan, kepentingan masyarakat setempat berdasarkan prakarsa masyarakat, hak asal usul, dan/atau hak tradisional yang diakui dan dihormati dalam sistem pemerintahan Negara Kesatuan Republik Indonesia. Desa memiliki kewenangan untuk mengatur dan mengurus kepentingan warganya dalam segala aspek, baik dalam pelayanan (public good), pengaturan (public regulation), dan pemberdayaan masyarakat (empowerment). Peranan pemerintah Desa memang dirasa sangat dibutuhkan dalam berbagai aspek kehidupan masyarakatnya, inovasi-inovasi baru serta perhatian pemerintah desa pada sarana prasarana desa juga sangat diperlukan demi terwujudnya pembangunan yang seutuhnya dalam pengelolaan keuangan desa (Hutami, 2017).

Pengelolaan keuangan desa menjadi salah satu isu strategis pada pemerintahan kabinet kerja di bawah kepemimpinan Presiden Jokowi, baik isu tentang otonomi daerah khususnya desa, maupun peraturan yang melingkupinya. Isu yang paling banyak dibicarakan adalah bahwa seluruh desa diperkirakan akan menerima kucuran dana transfer dari Anggaran Pendapatan dan Belanja Negara (APBN) untuk pembangunan desa. Komposisi kucuran dana desa mengalami peningkatan tiap tahunnya. Pemberian dana ke desa yang begitu besar, jumlah pelaporan yang beragam serta adanya titik kritis dalam pengelolaan keuangan desa tentunya menuntut tanggung jawab yang besar pula oleh aparat pemerintah desa. Oleh karena itu, pemerintah desa harus bisa menerapkan prinsip akuntabilitas dalam pengelolaan keuangan desa, dimana semua akhir kegiatan penyelenggaraan pemerintah desa harus dipertanggungjawabkan kepada masyarakat desa sesuai ketentuan (Fahri, 2017). Dengan demikian pengelolaan keuangan yang baik bertujuan untuk menghindari kasus korupsi dana desa. Ismail, Widagdo, \& Widodo (2016) menunjukkan bahwa permasalahan utama yang akan terjadi dalam mengelola dana desa sesuai Permendagri No. 113 tahun 2014 tentang pengelolaan keuangan desa adalah rendahnya pengetahuan kepala desa karena dalam proses pengelolaan dana desa tidak ada bantuan tenaga pendamping. Di sisi lain, Satriajaya (2017) menunjukkan bahwa masih terdapat beberapa proyek yang pengerjaannya hanya setengah-setengah dan proyek tersebut diberikan secara tidak merata sehingga masih ada beberapa RT yang tidak mendapatkannya. Proyek yang dimaksud adalah seperti semenisasi jalan sehingga menimbulkan adanya perilaku penyimpangan. Perilaku oportunistik (opportunistic behavior) merupakan perilaku yang berusaha mencapai keinginan dengan segala cara bahkan cara ilegal sekalipun (Gumaidi, 2016). Perilaku oportunistik ini akan mengeksploitasi peluang keuntungan jangka pendek dengan mengorbankan keuntungan jangka panjang. Penyimpangan yang mengarah pada tindakan fraud pada sektor publik, khususnya lembaga pemerintah dinyatakan Julianto (2012) sebagai sesuatu yang lumrah terjadi, karena adanya mental koruptif, pengaruh politik serta lemahnya penegakan hukum. 
Studi Dunn (2000) mengungkapkan bahwa kebijakan pemerintah yang tidak terimplementasikan dengan baik, biasanya disebabkan adanya inkonsistensi materi regulasi dan ketidaksesuaian dengan kondisi sebenarnya. Hal itu membuat dampak kebijakan itu tidak sesuai dengan apa yang dimaksudkan dalam tujuan dari kebijakan itu sendiri. Selain itu telah banyak desa yang sudah menerapkan tahapan-tahapan pencairan dan penyaluran dana desa sesuai dengan peraturan yang berlaku sehingga akan berdampak positif bagi pemerintah desa dan masyarakat. Namun demikian, masih banyak pula kendala-kendala yang dialami beberapa desa seperti penerapan fungsi manajemen terhadap pengelolaan keuangan desa tidak optimal, kurangnya SDM yang cakap dalam pengelolaan keuangan desa, masih banyak regulasi yang belum dapat terimplementasi, penyalurannya belum sesuai dengan ketentuan yang berlaku dan faktor lainnya (Astuti dan Yulianto, 2016). Dengan demikian perlu dilakukan pengkajian lebih mendalam mengenai perilaku oportunistik dalam pengelolaan keuangan desa. Penelitian tentang pengelolaan keuangan desa ini dilakukan di Desa Manggar (untuk alasan pertimbangan etis nama desa disamarkan) dengan memfokuskan pada pengelolaan keuangan desa melalui tahap perencanaan, pelaksanaan, pelaporan dan pertanggungjawaban. Hasil penelitian ini dapat memberikan kontribusi untuk menciptakan best practices dalam pengelolaan keuangan desa dengan melakukan perbaikan dan membangun mekanisme tata kelola yang baik untuk menghindari terjadinya praktik-praktik yang mengarah pada perilaku oportunistik.

\section{Kajian Teoritis}

\subsection{Telaah Penelitian Terdahulu}

Penelitian tentang pengelolaan keuangan desa telah dilakukan dalam beberapa studi yang relevan dengan hasil penelitian yang beragam karena perbedaan konteks dan subyek yang diteliti. Studi Triyani dan Handayani (2018) meneliti penerapan pengelolaan keuangan desa dan menemukan bahwa pengelolaan keuangan desa telah sesuai dengan peraturan yang berlaku yaitu peraturan Menteri Keuangan Nomor 49/2016 meskipun dalam praktiknya terdapat kendala yang disebabkan oleh perubahan kementerian dan kemampuan penyalur dana desa yang belum memadai. Studi Ahmad (2016) dengan pendekatan kualitatif meneliti pengelolaan keuangan desa berdasarkan UU No. 6 Tahun 2014 dan menemukan hasil bahwa pengelolaan keuangan desa pada tahun 2014 belum menerapkan transparansi dalam pelaporan keuangan desa yang disebabkan oleh pelaksanaan pemerintah desa, keterbatasan waktu dalam persiapan administrasi, sumber daya manusia yang kurang mendukung, dan pencairan dana yang terlambat. Penelitian Walukow, Kalangi, dan Pinatik (2017) pada desa Kauneran menemukan pada tahap perencanaan belum sesuai dengan regulasi Permendagri 113/2014 dan kurangnya partisipasi masyarakat menjadi penghambat dalam proses pengelolaan keuangan desa.

Sejalan dengan penelitian sebelumnya, studi Dewanti (2015) menganalisis perencanaan pengelolaan keuangan desa di Desa Boreng yang masih banyak ditemukan ketidaksesuaian antara perencanaan keuangan yang dilakukan dengan perencanaan keuangan desa berdasarkan Permendagri No. 37 Tahun 2007. Studi tentang disfunctional behavior dalam pengelolaan keuangan desa dilakukan oleh Satriajaya, Handajani dan Putra (2017) dengan pendekatan fenomenologi-hermeneutika untuk mengkaji pengalaman dan pemahaman pengelola keuangan di Desa Gambo Kabupaten Samanta. Hasil penelitiannya 
menyatakan bahwa dalam proses perencanaan dan pelaksanaan terjadi penyimpangan karena dokumen perencanaan yang disusun tidak sesuai dengan ketentuan yang ada. Adanya polisemi dan ambiguitas dalam pengakuan pendapatan desa diungkapkan dalam studi Satriajaya dkk, (2017) menunjukkan terjadinya berbagai penyimpangan dalam pengelolaan keuangan desa, terutama pengakuan PAD berdampak pada tindakan penyimpangan yang menjadi sebuah kleptokrasi yang dilegalisasikan.

Keterkaitan antara good governance dalam pengelolaan keuangan desa telah dilakukan dalam studi Astuti dan Yulianto (2016) pada desa-desa yang ada di Kecamatan Polokarto, Sukoharjo Jawa Tengah. Temuan penelitiannya mengungkapkan bahwa seluruh desa di Indonesia diperkirakan sudah akan menerima kucuran dana transfer dari Anggaran Pendapatan dan Belanja Negara (APBN) sehingga perlu adanya tata kelola yang baik dalam pengelolaan keuangan desa demi tercapainya pengelolaan manajemen yang lebih transparan bagi semua penggunaan laporan keuangan. Hasil lainnya dari penelitian tersebut juga mengungkapkan bahwa pengelolaan keuangan desa yang transparansi, akuntabel dan partisipatif merupakan aspek penting dalam menciptakan good governance dalam pengelolaan keuangan desa yang telah tertuang dalam UU No.14 tentang Desa. Studi Santoso (2015) tentang keabsahan pengelolaan keuangan desa mengungkapkan bahwa dalam penyusunan sumber pendapatan desa telah ditetapkan beberapa sumber pendapatan dalam APBDes terbagi atas tiga kelompok yaitu Pendapatan Asli Desa, transfer dan pendapatan lainnya. Kemungkinan terjadinya penyimpangan dalam suatu pengelolaan keuangan desa antara lain karena banyak pembiayaan maupun belanja yang diluar peraturan yang ditetapkan APBDes dan perolehan bukti pembayaran yang ilegal karena bendahara berusaha agar pembukuan yang dibuatnya bisa berjalan dengan tertib. Dengan demikian pengelolaan keuangan akan baik apabila didukung dengan pencatatan pembukuan serta bukti pendukung yang benar. Penelitian tentang faktor-faktor yang mempengaruhi perilaku oportunistik penyusunan anggaran dilakukan oleh Gumaidi (2016) untuk menganalisis pengaruh Pendapatan Asli Daerah (PAD), Sisa Lebih Perhitungan Anggaran (SiLPA), Dana Alokasi Umum (DAU) terhadap perilaku oportunistik penyusun anggaran Kabupaten/Kota di Provinsi Jawa Timur. Berdasarkan hasil penelitian ini menunjukan bahwa ketiga faktor tersebut (PAD, SiLPA dan DAU) mempengaruhi perilaku oportunistik penyusunan anggaran (OPA). Studi lainnya tentang pengelolaan dana desa di Desa Singopuran Kecamatan Kartasura Kabupaten Sukoharjo dilakukan oleh Riyani (2016) sudah tersampaikan untuk pembangunan dengan baik sesuai dengan rencana namun masih ada evaluasi yang perlu diperbaiki, seperti kurangnya rasa tanggungjawab antara perangkat desa dalam pengelolaan dana desa, masyarakat yang peduli terhadap pembangunan masih sedikit, dan kurangnya pertemuan untuk menyampaikan informasi alokasi dana desa terhadap masyarakat.

\subsection{Perspektif Agency Theory dan Pengelolaan Keuangan Desa}

Agency Theory mengargumentasikan fenomena dalam pengelolaan keuangan desa. Hubungan keagenan timbul manakala pihak pemberi amanah (principal) memberikan amanah kepada pihak lain (agent) guna melaksanakan tugas sesuai dengan yang diharapkan. Dalam hubungan keagenan, pemerintah desa selaku pihak yang diberikan amanah untuk mengelola dana masyarakat harus mempertanggungjawabkan amanah tersebut, sebaliknya rakyat selaku pemberi amanah akan memberi insentif pada pemerintah 
berupa kepercayaan politik (Ahmad, 2016). Teori keagenan menyatakan bahwa setiap orang cenderung berperilaku oportunis atau mementingkan dirinya sendiri dan memaksimalkan kemakmurannya melalui keputusan yang diambil dalam organisasi (Jensen dan Meckling, 1976). Bentuk kecenderungan perilaku agent untuk melakukan tindakan oportunistik, individu dikendalikan oleh kepentingan diri pribadi. Pada hubungan pertama yaitu antara pihak pemerintah desa dengan Badan Permusyawaratan Desa (BPD), konflik keagenan terjadi karena tidak adanya keseimbangan informasi antara pihak pemerintah desa yang pada hal ini sebagai agent dengan pihak masyarakat sebagai principal. Pihak pemerintah desa yang memiliki keunggulan informasi keuangan pada kinerja aktual cenderung memaksimalkan utilitasnya dan bertindak self-interest dalam pembuatan atau penyusunan APBDesa. Pratiwi (2016) mengungkapkan pihak pemerintah desa (agent) cenderung melakukan budgetary slack dengan tujuan untuk mengamankan posisinya dalam pemerintahan, sedangkan pihak BPD (principal) cenderung melakukan "kontrak semu" dengan pihak pemerintah desa karena memiliki discretionary power.

\subsection{Potensi Perilaku Oportunistik Pengelolaan Keuangan Desa}

Perilaku oportunistik (opportunistic behavior) atau oportunisme (opportunism) didefinisikan sebagai "mencari kepentingan pribadi atau diri sendiri dengan menggunakan tipu daya (tipu muslihat)" (Williamson, 1985 dalam Wibowo, 2017). Lebih lanjut Wibowo (2017) menyatakan perilaku oportunistik mengacu pada tindakan spesifik yang dilakukan oleh satu pihak, sehingga terjadi pengaturan yang tidak sama (tidak setara) dengan pihak lain yang berhubungan. Oportunisme mengarah pada tindakan, seperti memotong/menahan atau mendistorsi informasi penting, tidak memenuhi janji atau kewajiban, berbohong, atau berbuat curang. Dengan demikian, oportunisme menimbulkan perasaan kebencian dan frustasi pada pihak lain. Oleh karena itu perlu adanya pembinaan dan pendampingan terhadap pelaksanaan tugas untuk menghindari perilaku oportunistik tersebut.

Dalam pengelolaan keuangan desa penyimpangan dan perilaku oportunistik berpotensi terjadi. Menurut Permendagri No. 20 Tahun 2018 tentang Pengelolaan Keuangan Desa, pengelolaan keuangan desa merupakan keseluruhan kegiatan yang meliputi perencanaan, pelaksanaan, penatausahaan, pelaporan, dan pertanggungjawaban keuangan desa. Kepala Desa sebagai Kepala Pemerintahan Desa adalah pemegang kekuasaaan pengelolaan keuangan desa dan mewakili pemerintahan desa dalam kepemilikan kekayaan milik desa yang dipisahkan. Keuangan desa adalah semua hak dan kewajiban dalam rangka penyelenggaraan pemerintah desa yang dapat dinilai dengan uang termasuk didalamnya segala bentuk kekayaan yang berhubungan dengan hak dan kewajiban desa tersebut. Keuangan desa dikelola berdasarkan asas-asas transparan, akuntabel, partisipatif serta dilakukan dengan tertib dan disiplin anggaran. Pengelolaan keuangan desa dikelola dalam masa 1 tahun anggaran yakni mulai tanggal 1 Januari sampai dengan 31 Desember. Anggaran pendapatan dan belanja desa, selanjutnya disingkat APBDesa adalah rencana keuangan tahunan pemerintahan desa yang dibahas dan disetujui bersama oleh pemerintah desa dan Badan Permusyawaratan Desa, dan ditetapkan dengan Peraturan Desa.

Beberapa potensi terjadinya penyimpangan dalam tahapan pengelolaan keuangan desa dimungkinkan terjadi. Bentuk perilaku oportunistik dalam perencanaan keuangan desa seperti : (a) tidak melibatkan masyarakat dalam menyusun RPJMD hingga 
memasukkan program yang sifatnya mengarah pada kepentingan pribadi, (b) membuat rancangan anggaran biaya diatas harga pasar (kongkalikong antara aparatur desa dengan konsultan perencanaan) dan (c). pengawasan tidak maksimal serta (d) sisa dana yang terpakai sementara, atau meminjam tanpa mengembalikan ke Rekening Kas Desa. Pelaksanaan APBDesa dimulai ketika desa sudah menerima pendapatan berdasarkan rencana yang telah ditetapkan dalam APBDesa. Penerimaan dan pengeluaran desa dalam rangka pelaksanaan kewenangan desa dilaksanakan melalui rekening kas desa. Artinya pemerintah desa dilarang melakukan pungutan sebagai penerimaan desa selain yang ditetapkan dalam Perdes APBDesa. Bendahara menyimpan uang dalam Kas Desa pada jumlah tertentu dalam rangka memenuhi kebutuhan operasional pemerintah desa sesuai Peraturan Bupati setempat. Pengeluaran desa yang mengakibatkan beban APBDesa tidak dapat dilakukan sebelum rancangan Perdes tentang APBDesa ditetapkan menjadi Perdes. Dalam tahap pelaporan dan pertanggungjawaban, potensi terjadinya perilaku oportunistik antara lain adalah: (a) mempertanggungjawabkan pembiayaan pembangunan fisik dengan dana desa padahal proyek tersebut bersumber dari sumber lain, (b) pemangkasan anggaran publik kemudian dialokasikan untuk kepentingan perangkat desa dan (c) membuat kegiatan atau proyek fiktif yang dananya dibebankan dari dana desa, serta (d) bendahara keuangan desa berusaha agar pembukuan yang dibuat berjalan dengan tertib.

\section{Metode Penelitian}

Jenis penelitian ini adalah studi kasus dengan menggunakan pendekatan kualitatif deskriptif yang bertujuan mendapatkan deskripsi dan rincian yang utuh terkait perilaku oportunistik dalam pengelolaan keuangan desa. Penelitian ini menggunakan data primer dan data sekunder. Menurut Sugiyono (2017: 104), data primer adalah sumber data yang langsung memberikan data kepada pengumpul data. Data primer dapat dikatakan sebagai data yang dikumpulkan oleh peneliti sendiri. Dalam penelitian ini, data primer yang dimaksud adalah hasil wawancara dan hasil observasi secara langsung kepada pihak-pihak terkait pengelolaan keuangan. Data sekunder adalah data yang diperoleh dari sumber yang tidak langsung memberikan data kepada pengumpul data, misalnya lewat orang lain atau lewat dokumen (Sugiyono, 2017:104). Dalam penelitian ini data sekunder digunakan sebagai data tambahan yang berupa dokumen terkait daftar hadir musrenbang, APBDes, RPJMDes dan RKPDes dari Desa Manggar.

Informan dalam penelitian ini adalah merupakan pihak-pihak yang terlibat dalam proses perencanaan, pelaksanaan, pelaporan dan pertanggungjawaban keuangan desa yaitu: kepala desa, aparat desa sekretaris dan bendahara, ketua dan sekretaris Badan Permusyawaratan Desa (BPD), kaur perencanaan, kepala dusun dan masyarakat. Teknik Pengumpulan data dilakukan melalui wawancara, dokumentasi dan observasi. Merujuk pada Creswell (2015) analisis data dilakukan melalui tahapan pengumpulan data, reduksi data, uji keabsahan data, penyajian data, analisis data, dan penarikan kesimpulan dan verifikasi temuan.

Dalam penelitian kualitatif pengumpulan data dilakukan dengan observasi, wawancara mendalam, dan dokumentasi. Pada tahap awal peneliti melakukan penjelajahan secara umum terhadap situasi/obyek yang diteliti, dengan melihat, mendengarkan dan merekam semua data. Dengan demikian peneliti akan memperoleh data yang sangat 
banyak dan sangat bervariasi. Pada tahap awal ini, data yang dikumpulkan berupa RAB, APBDesa, RPJMDesa, dan RKPDesa. Pada tahap reduksi data, peneliti merangkum dan memilih informasi inti yang sesuai dengan fokus penelitian. Pemilihan dan perangkuman data dilakukan terhadap data yang diperoleh dari informan untuk mencari relevansinya dengan masalah penelitian. Reduksi data dilakukan untuk menghasilkan data yang dapat diverifikasi dan didukung oleh bukti yang kuat sehingga mempermudah peneliti untuk melakukan pengumpulan data yang selanjutnya, dan mencari kembali ketika dibutuhkan data dibutuhkan. Uji keabsahan data yang dilakukan setelah reduksi data, bertujuan untuk menguji kredibilitas dengan menggunakan teknik triangulasi sumber dan metode.

Pada tahap penyajian data dilakukan dalam bentuk uraian singkat sehingga dapat memudahkan peneliti untuk memahami kondisi yang terjadi dan dapat menentukan tahap selanjutnya yang akan dikerjakan. Data yang dapat disajikan oleh peneliti dalam penelitian ini digunakan untuk mengidentifikasi adanya perilaku oportunistik dalam perencanaan, pelaksanaan dan pelaporan pengelolaan keuangan desa. Pada tahap analisis data yang dilakukan peneliti adalah menganalisis kesesuaian dokumen-dokumen terkait antara perencanaan dan pelaporan pengelolaan keuangan desa di Desa Manggar dengan perencanaan dan pelaporan pengelolaan keuangan desa menurut Permendagri No. 20 Tahun 2018. Penarikan keseimpulan dan verifikasi dalam penelitian kualitatif didasarkan pada penyajian data dan reduksi data yang dapat menjawab masalah penelitian. Kesimpulan awal yang dikemukakan masih bersifat sementara, dan akan berubah bila tidak ditemukan bukti-bukti yang kuat yang mendukung pada tahap pengumpulan data berikutnya. Jika kesimpulan yang dikemukakan pada tahap awal, didukung oleh buktibukti yang valid dan konsisten saat peneliti kembali ke lapangan mengumpulkan data, maka kesimpulan yang dikemukakan merupakan kesimpulan yang kredibel.

\section{Hasil dan Pembahasan}

\subsection{Mekanisme Pengelolaan Keuangan Desa}

Mekanisme pengelolaan keuangan desa di Desa Manggar dimulai dengan pembentukan tim penyusun Rencana Kerja Pemerintah Desa (RKPDesa) yang dibuat oleh pemerintah desa. Tim ini melibatkan masyarakat secara umum yakni kepala desa sebagai pembina, sekretaris desa, kepala urusan perencanaan, lembaga-lembaga yang ada di desa, serta BPD. Tujuan diadakannya tim ini agar pembangunan desa dapat lebih terarah guna untuk meningkatkan kualitas hidup masyarakat desa. Mekanisme pembentukan Tim penyusunan RKPDesa yang dibuat oleh pemerintah desa Manggar telah sesuai dengan Permendagri No. 114 Tahun 2014 tentang pedoman pembangunan desa terdapat pada pasal 33 mengenai pembentukan tim penyusun RKPDesa. Tujuan adanya pembentukan tim sebelum adanya musyawarah perencanaan pembangunan adalah agar forum musyawarah lebih terarah dan tim tersebut dapat mempelajari mengenai RKPDesa tahun sebelumnya, program-program yang berjalan maupun tidak berjalan. Dengan demikian diharapkan tim penyusun dapat menjadi penengah apabila terdapat usulan maupun kegiatan program yang diminta oleh masyarakat. Selanjutnya, tim penyusun menyelaraskan usulan tersebut dengan peraturan-peraturan yang berlaku maupun dari RPJMDesa.

Dalam proses pengelolaan keuangan desa terdapat 4 tahapan yaitu perencanaan, pelaksanaan, pelaporan dan pertanggungjawaban. Hasil penelitian ini mendeskripsikan 
tentang pengelolaan keuangan desa dalam setiap tahapan pengelolaan keuangan desa. Pada proses perencanaan secara prosedural harus dilakukan berdasarkan program, skala prioritas, agenda kegiatan dan terdapat outcome yang jelas dari masing-masing kegiatan. Sementara untuk alokasi pendapatan desa yakni Dana Desa seharusnya hanya fokus untuk pemerintahan dalam bidang pembangunan fisik dan pemberdayaan kemasyarakatan. Pemerintah desa dalam menyusun program yang akan dilaksanakan harus dapat meningkatkan fasilitas kesehatan, pendidikan, pertanian, pengelolaan lingkungan hidup ekonomi masyarakat, serta perekonomian guna untuk meningkatkan kualitas hidup masyarakat di desa. Proses perencanaan pembangunan ini tertuang dalam Rencana Kerja Pemerintah Desa (RKPDesa). RKPDesa ini akan menentukan arah pembangunan desa dalam satu tahun kedepan. Dalam penyusunan RKPDesa ini harus berdasarkan fokus perencanaan pemerintah desa yang tertuang dalam Rencana Pembangunan Jangka Menengah Desa (RPJMDesa). RPJMDesa dan RKPDesa akan menjadi satu-satunya dokumen perencanaan desa untuk penyusunan APBDesa yang diatur melalui Peraturan Desa. Selanjutnya disesuaikan dengan program pembangunan pemerintah kabupaten, pemerintah kota serta pemerintah provinsi. Mengingat pentingnya RKPDesa, dibutuhkan peran dari pemerintah desa untuk dapat merancang apa saja yang menjadi prioritas pembangunan setahun kedepan

Dalam tahapan pelaksanaan, setiap pelaksanaan kegiatan-kegiatan yang dananya bersumber dari APBDesa termasuk didalamnya terdapat Dana Desa dilaksanakan oleh Pelaksana Teknis Pengelolaan Keuangan Desa (PTPKD). Kepala desa selaku pemegang kekuasaan pengelolaan keuangan desa berhak untuk menunjuk siapa saja untuk menjadi PTPKD. Berdasarkan wawancara dengan berbagai informan, PTPKD di Desa Manggar adalah sebagai berikut : a. sekretaris desa selaku koordinator PTPKD. b. Kepala Seksi bertindak sebagai pelaksana kegiatan. c. kaur Keuangan bertindak dalam urusan keuangan.

Menurut Peraturan Menteri Keuangan Nomor 49 tahun 2016 mengenai Tata Cara Pengalokasian Dana Desa, penyaluran dana desa dilakukan dengan cara pemindahbukuan dari Rekening Kas Umum Negara (RKUN) ke Rekening Kas Umum Daerah (RKUD) untuk selanjutnya dilakukan pemindahbukuan dari RKUD ke Rekening Kas Desa (RKD). Dalam pelaksanaan keuangan di desa Manggar, ada beberapa prinsip yang wajib ditaati mengenai penerimaan dan pengeluaran yang dilaksanakan melalui RKD. Seluruh penerimaan dan pengeluaran desa yang dilakukan oleh pemerintah desa dilaksanakan menggunakan RKD. Hal tersebut menjadikan sistem keuangan desa menjadi terpusat. Apabila ingin mencairkan dana dalam RKD wajib ditandatangani oleh kepala desa dan kaur keuangan. Berdasarkan hasil penelitian di lapangan, Pemerintah Desa Manggar dalam pelaksanaan di lapangan ditemukan adanya penghematan anggaran sehingga pelaksanaan tidak sesuai dengan yang dilaporkan dan tidak sesuai dengan yang dianggarkan. Diindikasikan terjadi mark-up yang dalam hal ini menunjukkan terjadinya pembengkakan nilai atau harga proyek. Dengan demikian dalam tahap pelaksanaan terdapat potensi perilaku oportunistik dalam pengelolaan keuangan desa.

Dalam melaksanakan tugas serta kewajibanya dalam pengelolaan keuangan desa, Pemerintah desa wajib memberikan laporannya kepada pemerintah diatasnya yakni camat, maupun kepada Bupati/Walikota. Disamping itu pemerintah desa dalam mempertanggungjawabkan kegiatannya wajib menyampaikan kepada masyarakat. 
Pelaporan Dana Desa tertuang dalam APBDesa. Menurut Permendagri Nomor 20 Tahun 2018 dalam melaksanakan tugas, kewenangan, hak dan kewajibannya dalam pengelolaan keuangan desa termasuk didalamnya Dana Desa, kepala desa wajib menyampaikan kepada Bupati/Walikota setiap periodik dan tahunan. Penyampaian laporan realisasi Dana Desa dilakukan paling lambat minggu keempat bulan juli tahun anggaran berjalan untuk semester satu dan paling lambat minggu keempat bulan januari tahun anggaran berikutnya untuk semester dua. Laporan realisasi Dana Desa dilaporkan kepada BPD. Pendalaman informasi terhadap informan mengungkapkan bahwa laporan realisasi Dana Desa yang dibuat oleh pemerintah desa Manggar dilakukan dalam setiap tahap, dikarenakan pencairan dana desa tahap selanjutnya wajib melampirkan laporan realisasi dana desa tahap sebelumnya. Oleh karena itu, pelaporan yang dilakukan oleh pemerintah desa kepada Bupati/Walikota hanya sebatas setiap tahapan. Pihak pemerintah desa juga menyampaikan laporan Dana Desa yang tercantum dalam APBDesa kepada BPD setiap tahunnya.

Konsekuensi dari penyelenggaraan pemerintah dalam hal pengelolaan Dana Desa yaitu pertanggungjawaban kepada beberapa pihak yang berkaitan. Dalam hal ini, pemerintah wajib membuat laporan dari pengelolaan dana desa. Penyampaian laporan realisasi dana desa secara tertulis oleh Kepala Desa kepada Bupati/Walikota. Dalam tata kelola pemerintahan yang baik maka pertanggungjawaban tidak hanya disampaikan kepada pemerintah, tetapi juga harus disampaikan kepada masyarakat. Temuan penelitian ini mengungkapkan bentuk pertanggungjawaban dari pemerintah desa Manggar mengenai pengelolaan Dana Desa yaitu belum adanya transparansi mengenai laporan dana desa. Laporan ini disampaikan kepada beberapa pihak baik kepada pemerintah kabupaten/kota dan masyarakat.

\subsection{Perilaku Oportunistik dalam Pengelolaan Keuangan Desa}

Berdasarkan pendalaman informasi terhadap sepuluh informan baik itu yang ada di pemerintah desa maupun masyarakat desa Manggar dapat diidentifikasi adanya perilaku oportunistik dalam pengelolaan keuangan desa. Hasil penelitian ini menjelaskan potensi terjadinya perilaku oportunistik dalam pengelolaan keuangan desa dalam setiap tahapan beserta bentuk atau pola yang dilakukan. Pada proses perencanaan keuangan di desa Manggar tidak terdapat adanya bentuk perilaku oportunistik yang terjadi karena dilihat dari setiap kegiatan selalu melibatkan masyarakat, penyampaian informasi dan keterbukaan kepada masyarakat. Proses perencanaan yang dilakukan di Desa Manggar terdapat tiga tahap, yaitu tahap pertama mulai dari musyawarah dusun guna untuk mendapatkan informasi mengenai laporan program periode berjalan dan sosialisasi, menampung permasalahan tiap dusun dan menerima usulan program untuk periode depan. Tahap kedua musyawarah desa terdapat agenda pembahasan melaporkan usulan program yang telah diverifikasi oleh tim, dan membuat draft musrenbang. Tahap ketiga musrenbang dilakukan agenda pembahasan menetapkan RKPDesa dan menetapkan RAPBDesa.

Pelaksanaan merupakan tahapan yang berkaitan dengan tindakan penting untuk mewujudkan tujuan akhir yang telah ditetapkan dari setiap kegiatan yang telah direncanakan secara matang dan terperinci melalui perencanaan atau Musrenbang. Berdasarkan informasi yang diperoleh dari beberapa informan menyatakan bahwa dalam proses pelaksanaan di lapangan tidak sesuai dengan yang dilaporkan dan tidak sesuai dengan perencanaan, terutama berkaitan dengan indikasi terjadinya mark-up anggaran, 
penyelewengan dalam penggunaan anggaran dana desa yang dilakukan oleh pemerintah desa. Pada saat pembelanjaan anggaran dilakukan, selisih lebih antara harga barang yang dianggarkan dan harga barang sebenarnya tidak sesuai dengan yang direncanakan. Alasan yang dikemukakan adalah untuk menghemat anggaran, namun nilai yang dilaporkan tidak sama dengan pelaksanaannya.

Pada tahapan pelaporan dan pertanggungjawaban mengindikasikan adanya potensi terjadinya perilaku oportunistik. Pada tahap ini sangat jelas terjadi perilaku oportunistik yang dilakukan dalam bentuk manipulasi laporan keuangan yang bertujuan untuk membuat laporan keuangan sesuai dengan anggaran yang direncanakan sebelumnya dan seolah-olah tidak terjadi kesalahan dalam pembukuan. Selain perilaku oportunistik berupa manipulasi laporan keuangan, menurut pengakuan Kepala Desa bahwa bendahara diberikan wewenang penuh oleh kepala desa untuk membuat laporan keuangan sebaik mungkin meskipun berbeda dengan fakta yang terjadi. Padahal penyusunan dan pertanggung jawaban laporan keuangan adalah tanggung jawab bersama PTPKD, bukan hanya tanggung jawab bendahara desa. Berdasarkan pernyataan diatas sangat jelas bahwa kepala desa memberikan wewenang penuh kepada bendahara desa terkait pelaporan keuangannya tanpa perlu adanya pengawasan. Seharusnya dalam pelaksanaan hingga pelaporan keuangan desa, kepala desa dibantu oleh sekretaris desa, kepala seksi, dan bendahara, serta pengawasan yang dilakukan oleh BPD tidak mungkin bendahara bekerja dengan sendirinya. Kemudian saat pembukuan dibuat sebaik mungkin seakan-akan tanpa terjadinya indikasi penyelewengan atau manipulasi laporan keuangan desa sehingga pembukuan yang dibuat terlihat baik-baik saja.

Hasil penelitian ini mengkonfirmasi tentang perlunya best practices dalam pengelolaan keuangan desa yang memerlukan keterlibatan masyarakat dan pengawasan dari masyarakat. Mekanisme tata kelola keuangan desa diperlukan dalam aspek pelaksanaannya maupun aspek pertanggungjawaban dan pelaporan yang akuntabel. Untuk mencapai tujuan ini diperlukan partisipasi masyarakat mulai dari perencanaan sampai dengan pertanggungjawaban serta penguatan regulasi yang mengatur sanksi terhadap pelanggaran. Secara operasional, hasil penelitian ini mengarah pada pentingnya tranparansi dalam pengelolaan keuangan desa dalam bentuk sosialisasi mengenai prioritas penggunaan dana desa kepada masyarakat agar masyarakat mengetahui proses implementasi penggunaan dana desa melalui media informasi seperti website desa yang dapat diakses oleh masayarakat. Pemerintah desa juga perlu meningkatkan kompetensi dan pengetahuan yang memadai tentang pengelolaan keuang desa sehingga diperlukan sosialisasi dan pengenalan terkait dengan kebijakan-kebijakan dan tata cara pengelolaan keuangan desa kepada perangkat desa, serta BPD sebaiknya melakukan pengawasan yang lebih baik terhadap pengelolaan keuangan desa.

\section{Kesimpulan, Implikasi dan Keterbatasan}

Hasil penelitian ini mengungkapkan tentang perilaku oportunistik dalam pengelolaan keuangan desa yang dilakukan oleh pemerintah desa Manggar melalui dokumentasi, observasi dan pendalaman wawancara dari informan terpilih. Pada tahap perencanaan tidak terdapat peluang terjadinya perilaku oportunistik dalam pengelolaan keuangan desa. Hal ini karena dalam setiap kegiatan perencanaan selalu melibatkan 
masyarakat dan dalam proses perencanaan sudah sesuai dengan aturan yaitu dilakukan musyawarah sebanyak 3 kali yaitu musyawarah tingkat dusun (musdus), musyawarah tingkat desa (musdes), dan musyawarah perencanaan pembangunan desa (musrenbang). Dalam tahap pelaksanaan diindikasikan terjadi perilaku oportunistik yang dilakukan dalam pola pelaksanaan kegiatan yang tidak sesuai dengan perencanaan dan kegiatan yang dilaksanakan tidak sesuai dengan yang dilaporkan. Dalam tahap pelaporan dan pertanggungjawaban terjadi indikasi terjadinya manipulasi laporan keuangan sebagai bentuk perilaku oportunistik pengelolaan keuangan desa dan belum adanya transparansi kepada masyarakat berupa informasi APBDes. Pelaksanaan kegiatan tidak sesuai dengan yang dilaporkan, meskipun dalam pelaporan pertanggungjawaban yang dilaporkan seakanakan telah sesuai dengan perencanaannya. Dalam membuat laporan keuangan kepala desa memberikan kewewenangan kepada bendahara desa tanpa adanya pengawasan dalam mengelola pencatatan dan pelaporan pengelolaan keuangan desa.

Pengelolaan keuangan desa yang menimbulkan konflik antara pemerintah desa dan masyarakat. Konflik yang terjadi karena adanya perilaku oportunistik pemerintah desa dalam bentuk pelaksanaan kegiatan pengelolaan keuangan desa yang tidak transparan kepada masyarakat. Implikasi praktis penelitian ini memberikan sumbangan pemikiran bagi pemerintah daerah dalam menyusun kebijakan terkait pengelolaan keuangan desa, serta bagi pemerintah desa terkait pengelolaan keuangan desa agar lebih transparan dan akuntabel sehingga terhindar dari perilaku oportunistik. Dalam aspek kebijakan, hasil penelitian ini memperkuat pentingnya mekanisme tata kelola dalam mengimplementasikan pengelolaan keuangan desa secara lebih baik, mulai dari tahap perencanaan, pelaksanaan, pelaporan dan pertanggungjawaban sesuai dengan acuan UU No. 6 Tahun 2014 dan Permendagri No. 20 Tahun 2018. Lingkup penelitian ini hanya terbatas pada satu desa dengan informan yang relatif terbatas serta kurangnya keterbukaan dari pemerintah desa terkait pengelolaan keuangan desa, sehingga penelitian selanjutnya dapat dilakukan di beberapa desa, memperluas informan dan menggunakan pendekatan penelitian yang lebih komprehensif.

\section{Daftar Pustaka}

Ahmad, Nirwana. (2016). Pengelolaan Keuangan Desa Berdasarkan UU No 6 Tahun 2014 (Studi Kasus Pada Desa di Kecamatan Baranti Kabupaten Sidenreng Rappang). Skripsi tidak Dipubliaksikan. Universitas Islam Negeri Alauddin Makasar

Astuti, T.P dan Yulianto. (2016). Good Governance Pengelolaan Keuangan Desa Menyongsong Berlakunya Undang-Undang No. 6 Tahun 2014. Berkala Akuntansi dan Keuangan Indonesia 1(1), 1-14

Creswell, John W. (2015). Penelitian Kualitatif \& Desain Riset. Yogyakarta: Pustaka Pelajar.

Dewanti, E.D.W. (2015). Analisis Perencanan Pengelolaan Keuangan Dea di Desa Boreng (Studi Kasus Pada Desa Boreng Kecamatan Lumajang Kabupaten Lumanjang). Skripsi tidak dipublikasikan. Universitas Jember

Dunn, William N. (2000). Pengantar Analisis Kebijakan Publik. Yogyakarta: Hanindita Graha Widya. 
Fahri, Lutfhi. (2017). Pengaruh Pelaksanaan Kebijakan Dana Desa Terhadap Manajemen Keuangan Desa Dalam Meningkatkan Efektifitas Program Pembangunan Desa. Jurnal Publik Jurnal Ilmiah Bidang Ilmu Administrasi Negara 11 (1), 75-88.

Gumaidi, Aan. (2016). Determinan Perilaku Oportunistik Penyusunan Anggaran. Jurnal Publikasi Universitas Muhammadiyah Surakarta, 1-12

Hutami. (2017). Analisis Pengelolaan Alokasi Dana Desa Di Desa Abbatireng Kecamatan Gilireng. Skripsi. Universitas Hasanuddin Makassar.

Ismail, Widagdo, dan Widodo. (2016). Sistem Akuntansi Pengelolaan Dana Desa. Jurnal Ekonomi Dan Bisnis 19 (2), 323-340.

Jensen, M.C \& W.H. Meckling. (1976). Theory of the firm: Managerial behavior, agency costs and ownership structure. Journal of Financial Economics 3 (4), 305-360

Julianto, E. (2012). Fraud dalam Pengelolaan Keuangan Negara. Seminar Nasional Praktik Akuntansi Dalam Dunia Kerja (halaman 1-23), Universitas Atmajaya Yogyakarta

Permendagri No. 113 tahun 2014 tentang pengelolaan keuangan desa

Permendagri No. 20 Tahun 2018 tentang Perubahan Pengelolaan Keuangan Desa

Peraturan Menteri Keuangan Nomor 49 tahun 2016 mengenai Tata Cara Pengalokasian Dana Desa

Permendagri No. 114 Tahun 2014 tentang pedoman pembangunan desa

Pratiwi, Tica. (2016). Pengaruh Pengetahuan Penganggaran Terhadap Peran DPRD Dalam Pengawasan APBD. Skripsi tidak dipublikasikan. Universitas Bengkulu.

Riyani, Nunuk. (2016). Analisis Pengelolaan Dana Desa (Studi Kasus di Desa Singopuran Kecamatan Kartasura Kabupaten Sukoharjo Tahun 2016. Skripsi Tidak Dipublikasikan Universitas Muhammadiyah Surakarta.

Satriajaya, Johan; L.Handajani, dan I.N.N.A Putra.(2017).Polisemi dan Ambiguitas Dalam Pengakuan Pendapatan Desa. Jurnal Akuntansi Multiparadigma. 6 (1), 107-123.

Santoso, Heri. (2015). Keabsahan Pengelolaan Keuangan Desa. Jurnal Kebijakan dan Manajemen Publik 3 (2), 117-240

Satriajaya, Johan. (2017). Studi Fenomenologi-Hermeneutika: Disfunctional Behavior Dalam Pengelolaan Keuangan Desa Di Kabupaten Sumbawa. Tesis. Universitas Mataram.

Shulthoni. (2017). Perilaku Oportunistik Legislatif Dalam Penganggaran Daerah. Jurnal Akuntansi Dan Ekonomi Bisnis 6 (1), 31-39.

Sugiyono. (2017). Metode Penelitian Kualitatif. Alfabeta: Bandung.

Triani dan Handayani. (2017). Praktik Pengelolaan Keuangan Dana Desa. Jurnal Akuntansi Multiparadigma 9 (1), 136-155

Undang-Undang Republik Indonesia Nomor 6 tahun 2014 tentang Desa.

Walukow, Kalangi, dan Pinatik. (2017). Analisis Perencanaan Pengelolaan Keuangan Desa Sesuai Dengan Permendagri No. 113 Tahun 2014. Jurnal Riset Akuntansi Going Concern 12 (2), 266-275.

Wibowo. (2013). Perilaku Oportunistik Dalam Hubungan Kemitraan. Jurnal Bina Ekonomi $17(2), 86-108$ 